\title{
The Banking Union: Agencies and the Lesson from the US
}

\section{Institute of}

European Law

\section{Luigi Lonardo (King's College London)}

\section{Working Papers}

\section{Paper: \\ $07 / 2016$}

(C) The Author(s)

Institute of European Law Birmingham Law School

University of Birmingham

Edgbaston

Birmingham

B15 2TT

United Kingdom

For more information on the IEL, see:

birmingham.ac.uk/IEL

For more information on this Working Paper Series, please contact:

Mr Robert Doolan, IEL Administrator: iel@contacts.bham.ac.uk 


\title{
The Banking Union: Agencies and the Lesson from the US
}

\author{
Luigi Lonardo, Phd Candidate, King's College London
}

\section{Introduction}

Independent agencies, despite not being new to the $\mathrm{EU}^{1}$, have proliferated since the 2008 crisis. Agencies have been one of the legal responses common to both waves of the crisis: the 20082012 financial crisis and the 2012 Euro-zone crisis ${ }^{2}$.

The first wave sparked as regulatory response, since 2010, the creation of a the internal-marketwide European System of Financial Supervision (ESFS) ${ }^{3}$. The ESFS is composed of National Competent Authorities as well as of new EU agencies, created to strengthen and control EU financial system governance. These agencies are the European Systemic Risk Board ${ }^{4}$; the three sectoral European Supervisory Authorities (ESAs): the European Banking Authority (EBA) ${ }^{5}$, the European Insurance and Occupational Pensions Authority (EIOPA) ${ }^{6}$, and the European Securities and Markets Authority (ESMA) ${ }^{7}$, and a Joint Committee, which coordinates them.

The supervisory powers transferred to these ESAs were, as Moloney notices ${ }^{8}$, relatively contained. The considerations that limited the powers of the ESAs were political and legal. Politically, the fiscal costs which the initial series of crisis-era bank rescues by Member States imposed on domestic tax -payers ${ }^{9}$ shaped the profound resistance by some Member States ${ }^{10}$ to

\footnotetext{
${ }^{1}$ Paul Craig, EU Administrative Law (OUP 2012) 144-146.

${ }^{2}$ Christos Hadjiemmanuil, "Bank Resolution Financing in the Banking Union" LSE Law, Society and Economy Working Papers 6/2015, 5-6 constructs a slightly different narrative of the crisis, dividing in three waves.

${ }^{3}$ Together with two mechanisms originally formed outside the framework of the Union: first a temporary collective mechanism for economic rescue, the European Financial Stabilization Fund, and then a permanent mechanism, the European Stability Mechanism.

${ }^{4}$ Regulation (EU) No 1092/2010 of the European Parliament and of the Council of 24 November 2010 on European Union macro-prudential oversight of the financial system and establishing a European Systemic Risk Board (EU) No 1092/2010.

${ }^{5}$ Regulation (EU) No 1093/2010 of the European Parliament and of the Council of 24 November 2010 establishing a European Supervisory Authority (European Banking Authority), amending Decision No 716/2009/EC and repealing Commission Decision 2009/78/EC.

${ }^{6}$ REGULATION (EU) No 1094/2010 OF THE EUROPEAN PARLIAMENT AND OF THE COUNCIL of 24 November 2010 establishing a European Supervisory Authority (European Insurance and Occupational Pensions Authority), amending Decision No 716/2009/EC and repealing Commission Decision 2009/79/EC.

${ }^{7}$ Regulation (EU) No 1095/2010 of the European Parliament and of the Council of 24 November 2010 establishing a European Supervisory Authority (European Securities and Markets Authority), amending Decision No 716/2009/EC and repealing Commission Decision 2009/77/EC.

${ }^{8}$ Niamh Moloney, "European Banking Union: Assessing its Risks and Resilience" (2014) 51 Common Market Law Review 1609.

${ }^{9}$ The public capital injected into EU banks over 2008 - 2012 is estimated to be in the region of $€ 413.2$ billion, amounting to $3.2 \%$ of EU GDP in 2012: Commission, European financial stability and integration report 2013 (2014), SWD (2014)170, p. 74.
} 
the transfer of executive powers with fiscal implications to the EU. Legally, the restrictions which apply to EU agencies under the Meroni doctrine limited the extent to which the European Supervisory Authorities could be empowered to take supervisory decisions ${ }^{11}$.

However, by 2012 Euro area Member States entered a new phase of economic distress. The catastrophic consequences felt in some Euro-zone countries as a consequence of the sovereign crisis $^{12}$, pushed MSs to set up the Banking Union, which entailed the transfer of significant supervisory and regulatory powers to the Single Supervisory Mechanism ${ }^{13}$ and the Single Resolution Mechanism ${ }^{14}$. However, given the high stakes of the decisions of these bodies, they give rise to concern of judicial protection, political and legal accountability. However, they have been established despite these concerns because it was felt necessary to overcome "political and legal obstacles previously thought insurmountable" 15 . In other words, it was the worsening of the crisis that forced the MSs to come up with such a solution.

Is this choice justified?

In order to answer this question, and to contribute at sketching a theoretical framework of administrative law under which to understand the developments of the Banking Union legal construction, this paper draws insight from the US experience.

First, the paper explores the concern over the judicial and democratic control over the acts of two agencies created during the second wave, the Eurozone crisis. They are Banking Union agency, even though one of them, the Supervisory board, is technically not an agency. The Supervisory Board, of the ECB, for the purposes of this analysis, will be considered a de facto agency ${ }^{16}$.

This paper considers the two most recent boards of appeals, which are independent commissions which resolve disputes related to the body or agency. They are established by secondary legislation in the context of the Banking Union: the SSM Resolution (together with a Decision of the ECB) and the SRM Resolution. These boards of appeals are ad hoc independent commissions which resolve disputes related to acts of the agency itself.

The Administrative Board of Review carries out an internal administrative review of some decisions taken by the European Central Bank (ECB) regarding the prudential supervision of credit institutions.

The Appeal Panel of the Single Resolution Mechanism. The Board of Appeal hears appeals against the decisions of the Single Resolution Board within the SRM. The paper explores

\footnotetext{
${ }^{10}$ The main conflict line was between the UK (rigidly opposed to any transfer of powers with fiscal consequences) and often supported by Spain and the Czech Republic, and France, often supported by Italy,

${ }^{11}$ Case 9/56, Meroni v. High Authority [1957-1958] ECR 133.

${ }^{12}$ C Hadjiemmanuil (n 2) 3 .

${ }^{13}$ Council Regulation (EU) No 1024/2013 of 15 October 2013 conferring specific tasks on the European Central Bank concerning policies relating to the prudential supervision of credit institutions (hereinafter, the SSM regulation)

${ }^{14}$ Regulation (EU) No 806/2014 of 15 July 2014 establishing uniform rules and a uniform procedure for the resolution of credit institutions and certain investment firms in the framework of a Single Resolution Mechanism and a Single Resolution Fund and amending Regulation (EU) No 1093/2010 (Hereinafter, SRM Regulation)

${ }^{15} \mathrm{~N}$ Moloney (n 8).

${ }^{16}$ Definition is also in Harlow and Rawlings, Process and Procedure in EU Administration (Hart 2014) 292.
} 
the main legal issues that arise for the judicial protection of physical and legal persons who can challenge the measures of these agencies.

Second, the paper draws insights from the creation of a unitary market in the United States. Much like the EU since 2008, nineteenth-century United States also experienced debt crises and default. The classical study of Skowroneck ${ }^{17}$ shows that the US reacted with new administrative capacities and policy instruments to preserve the market. Even before the establishment of the Interstate Commerce Commission in 1887, which marks the emergence of regulatory agencies, the expansive role for administrative discretion emerged under broad delegations of Congressional authority. As authors such as Mashaw and Perry ${ }^{18}$ have explained by analysing the role of administrative role in APD, the Congress generated substantial regulatory activity on the part of administrative agencies, through permissive acceptance of administrative adjudicatory and enforcement authority. Thus, APD offers an important reference point for understanding the institutional allocation of power. It shows that integration also passes by stages where agencies have to enjoy a rather large amount of discretion.

This paper contributes to conceptualising the Euro-crisis by applying a "lesson" from American Political Development (APD) and Independent Agencies (IAs) in the European Union (EU). APD is the study of the evolution and integration of the market of the United States. It's a multidisciplinary field of study, to which economists, lawyers, political scientists and historians contribute APD studies the construction and evolution of US institutions, broadly defined as to include for example the unitary market. Building, regulating and then liberalising an internal market, is arguably EU's most vital task. The theories of APD can be applied to the latest Banking Union agencies in order to gain a better understanding of the fundamental tension between the need for specialised decision-making by unelected IAs and the commitment to be governed by the people.

The paper argues that IAs may be necessary to achieve this aim. It explores a potential trade-off between the potential loss of democratic scrutiny and more efficient governance. IAs may indeed prove -as a result of the crisis- to be a tool around which further integration will pivot. Absent sound finances, regulatory agencies may be the most efficient instrument to achieve the desired policies.

\section{The Banking Union's newest agencies}

In constitutional and administrative law, independent agencies enjoy a special ${ }^{19}$ and somehow ambiguous status. This is true for the EU and for the US alike. In the US are so-called independent agencies, those entities where at least one individual is appointed by the president to a full-time, fixed-term position with the advice and consent of the Senate and has protection, by statute or custom, against summary removal. These constitute what is sometimes referred to as a

\footnotetext{
${ }^{17}$ Stephen Skowroneck, Building a New American State. The Expansion of National Administrative Capacities, 1877-1920 (CUP 1982).

18 J. L. Mashaw and A. Perry, "Administrative Statutory Interpretation in the Antebellum Republic" (2009) 7 Michigan State Law Review 7.

${ }^{19}$ Paul Verkuil, “The Purposes and Limits of Independent Agencies (1988) Duke Law Journal 257
} 
"headless fourth branch" of the Government ${ }^{20}$, i.e., a haphazard deposit of irresponsible agencies and uncoordinated powers. Despite this famous definition, however, American IAs rather range on a spectrum whereby each agency enjoys more or less independence and discretionary power depending on their statutory authority, structure, traditions, or culture ${ }^{21}$.

The United States has known the administrative practice of delegating power to independent agencies at least since the late $19^{\text {th }}$ century $^{22}$. But while in the US "independence" is used with reference to the president ${ }^{23}$, or to the party system $^{24}$, in the EU independence is best understood with reference to political games ${ }^{25}$, as a way of fostering integration without this passing by the political arena.

The reasons for this preference are the problems to be addressed are highly technical and agencies have technical expertise to solve them ${ }^{26}$; that the economic principle of the division of labour allows political institutions to focus on core policy-making while specialised agencies concentrate on sectorial task.s; the spread of agencies beyond Brussels and Luxembourg adds to the visibility of the Union ${ }^{27}$; Agencies have proved particularly relevant in field of shared competences, when the implementation of new policies at Community level needs to be accompanied by close cooperation between the Member States and the $\mathrm{EU}^{28}$; that regulating a subject costs less than putting money on the market; or a mix of these ${ }^{29}$.

However, the new agencies are troublesome from the standpoint of judicial protection. The problem is of the remedies available against the decisions of these agencies give rise to issues of political and legal accountability ${ }^{30}$. Not all agree with this analysis. Some commentators have

\footnotetext{
${ }^{20}$ The president's committee on administrative management, report of the committee with studies of administrative management in the federal government (1937).

${ }^{21}$ Marshall J. Breger and Gary J. Edles, Independent Agencies in the United States: Law, Structure, and Politics (OUP 2015). As a matter of example, many multimember agencies have the full range of regulatory authority, that is, they can issue rules, take administrative action to enforce their statutes and regulations, and decide cases through administrative adjudication. Some oversee a specific area of the economy. For example, the Federal Energy Regulatory Commission (FERC) regulates interstate aspects of the electric power, natural gas, oil pipeline, and hydroelectric industries; and the Securities and Exchange Commission (SEC) administers the federal securities law and regulates firms engaged in the purchase or sale of securities, investment companies, and people who provide investment advice. Others have substantive, subject-matter responsibilities that cut across industry lines. For example, the Federal Trade Commission (FTC) enforces a variety of federal antitrust and consumer protection statutes.

${ }^{22}$ Marshall J. Breger and Gary J. Edles (n 21) 1.

${ }^{23}$ This was the understanding of the US Supreme Court in Humphrey's Ex'r v. United States, 295 U.S. 602 , 624, 625-26 (1935)

${ }^{24}$ Martin Shapiro, "The Problem of Independent Agencies in the United States and the European Union" (1997) 4 Journal of European Public Policy 276.

${ }^{25}$ As poignantly explained by Shapiro almost twenty years ago: "If currently direct routes to further political integration of the Union are blocked, following Haas's old arguments about the World Health Organization and the $\mathrm{UN}$, further growth can be achieved indirectly through the proliferation of small, limited jurisdictions, allegedly 'technical agencies' that will appear politically innocuous". Shapiro (n 24) 281

${ }^{26}$ Paul Craig, (n 1) 141.

${ }^{27}$ Communication from the commission to the European Parliament and the Council European agencies - The way forward Comm (2008) 323, 1.

${ }^{28}$ Comm 2008 (n 27) 323, 5.

${ }^{29}$ Commission, The operating framework for the European Regulatory Agencies COM(2002) 718 final, p 10.

${ }^{30}$ See below Section
} 
taken the view that, as far as the SRM is concerned, "The rules on judicial protection follow contemporary standards in this field"31 and that the SRM's judicial protections is "by and large, adequate", 32

Some authors, instead, have voiced concerns about the the application of the rule of law to procedures followed by the $\mathrm{SRB}^{33}$. Others considered that "the scarce attention paid to the good governance values of due process and accountability" was "a striking feature" of the Commission's original plans for banking supervision ${ }^{34}$. The principle of good administration is enshrined in Article 41 of the EU Charter of fundamental rights synthetizing some of the case law of the Court of Justice in this field ${ }^{35}$ is of particular relevance to administrative procedures. According to the Charter the right to good administration requires that decisions be taken pursuant to procedures which guarantee fairness, impartiality and timeliness ${ }^{36}$. An element of the good administration principle is the duty of care, which includes the right of every person to have his or her affairs handled impartially, fairly and within a reasonable time ${ }^{37}$. Impartiality requires the absence both of arbitrary action and of unjustified preferential treatment including personal interest ${ }^{38}$. The three institutions, in a 2012 joint statement, warned specifically on the importance of the impartiality and independence of the Members of the Boards of Appeals of regulatory agencies ${ }^{39}$.

There is a tension between the struggle to efficiency and the need to ensure a standard of democratic accountability in line with the general principles of EU law and of the Charter of fund rights.

\subsection{The Administrative Board of Review (ABR)}

\footnotetext{
2.3 Areas of tension

${ }^{31}$ Georgios I. Psaroudakis \& Basil C. Scouteris Greek report, XXVII FIDE Congress (Vol 1, Wolters Kluwers 2016) 22.

${ }^{32}$ Stéphanie Laulhé Shaelou and Phoebus L. Athanassiou,Cypriot report, XXVII FIDE Congress (Vol, Wolters Kluwers 2016) 21.

${ }^{33}$ Eilis Ferran, Niamh Moloney, Jennifer Payne (eds), The Oxford Handbook of Financial Regulation (OUP 2015) 478 , with reference to the SRB adoption of a resolution scheme.

${ }^{34}$ C Harlow and R Rawlings (n 16) 294.

${ }^{35}$ The CJEU has referred to good administration principles since the very early case-law: Joined Cases 7/56, 3/57 to 7/57 Algera and Others $v$ Common Assembly of the ECSC [1957] ECR 0039; Case 32/62 Alvis [1963] ECR 49, para 1A; Joined Cases 56 and 58/64 Consten and Grundig v Commission [1966] ECR 299; Case 64/82 Tradax v Commission [1984] ECR 1359; see the Explanations Relating to the Charter Of Fundamental Rights, Doc. 2007/C 303/02, at http://eur-lex.europa.eu/LexUriServ/LexUriServ.do?uri=OJ:C:2007:303:0017:0035:en:PDF

${ }^{36}$ Directorate General for internal policies, “The General Principles of EU Administrative Procedural Law”2015, 18

${ }^{37}$ Art 41(1) Charter.

${ }^{38}$ Case T-146/89 Williams $v$ Court of Auditors [1991] ECR II-1293, para. 40; Case T-305/94 Limburgse Vinyl Maatschappij $v$ Commission [1999] ECR II-931, paras. 317ff.

${ }^{39}$ Joint statement on decentralised agencies and the subsequent common approach of Parliament, the Council and the Commissions signed on June 19, 2012.
} 
The SSM regulation requires the ECB to establish an $\mathrm{ABR}^{40}$ and to adopt a decision setting out its operating rules, with the objectives of strengthening the legal protection of natural and legal persons and for reasons of procedural economy ${ }^{41}$. In compliance with this provision, the ECB has adopted a decision on 14 April 2014 establishing the ABR and its Operating Rules ${ }^{42}$. The analysis that follows is structures around four questions: what acts can be challenged before the board? By whom? On what ground? And what are the effects of the challenge?

- What can be challenged?

Under Art 24(1) SSM Regulation and 7(1) ABR Decision, the ABR hears appeals on the decisions adopted by the ECB in the exercise of its supervisory tasks as they have been conferred upon it by the SSM mechanism.

- By whom?

Pursuant to Article 24 (5) SSM Regulation, any natural or legal person may request a review of an ECB decision if such decision is addressed, or is of a direct and individual concern, to that person. These requirements are the same as in an action for annulment pursuant to Article 263 (4) TFEU, therefore the case law of the CJEU should be applicable to determine the rules on standing. A request for review to the ABR (called a 'notice of review' in the ABR Decision) shall be made in writing, including a statement of grounds. The time limit is one month from the date of notification of the decision to the person requesting the review, or, in the absence of a notification, of the day on which it became known to such person.

- On what grounds?

If the request is admissible, the ABR carries out an internal administrative review with regard to the procedural and substantive conformity of supervisory decisions with the SSM Regulation ${ }^{43}$. In the light of Article 4 (3) SSMR, this means that the ABR will fully review the legality of the decision against the entire corpus of Union law and, this include, crucially, national implementing law, as applied by the ECB. Pursuant to the ABR Decision, the legal review shall, however, be limited to an examination of the grounds relied on by the applicant as set out in the notice of review, making careful preparation of the notice of review essential ${ }^{44}$. However, this restriction may be in contrast with the SSM Regulation. Article 24 SSM Regulation does not contain any such limitation. Moreover, the ABR Decision itself explicitly states that, when preparing a new draft decision, the Supervisory Board will not be limited to an examination of the grounds relied upon by the applicant in the notice of review.

- What are the effects?

\footnotetext{
${ }^{40}$ For an overview: The SSM Framework Regulation. Part 2: Administrative procedure, legal remedies and transitional provisions, June 2014.

${ }^{41}$ Preamble SSM Regulation.

${ }^{42}$ Decision of the European Central Bank of 14 April 2014 concerning the establishment of an Administrative Board of Review and its Operating Rules (ECB/2014/16) (Herein, the ABR Decision).

${ }^{43}$ Art 10(1) ABR Decision, Art 24(1) SSM Regulation.

${ }^{44}$ Art 10(2) ABR Decision.
} 
Much though actions for annulment before the CJEU, a request for review submitted to the ABR pursuant to Article 24 (5) SSM Regulation does not automatically have suspensory effect of the appealed decision. However, the Governing Council, upon a proposal being made by the ABR directly to it and not via the Supervisory Board, may suspend the application of the decision under review. If the applicant wishes to apply for the review to be given suspensory effect, it shall state the grounds for such application. The ABR Decision provides that the request for review must be admissible and not obviously unfounded In addition, it must be established that the immediate application of the contested decision may cause irreparable damage to the applicant.

Moreover, under Article 34 SSMFR the ECB may suspend, ex officio, the application of a supervisory decision in the initial decision itself, or, even outside of a review procedure before the ABR, upon the request of the addressee of a supervisory decision.

If the request is deemed admissible, the ABR expresses its opinion on the matter brought to its attention "within a period appropriate to its urgency, but no later than two months from the receipt of the request". The opinion shall be in writing and contain reasons. The opinion of the $\mathrm{ABR}$, however, is not binding, and does not automatically replace the decision of the ECB. The ABR simply remits the case for preparation of a new draft decision to the Supervisory Board. The Supervisory Board shall, taking into account the opinion of the ABR, but not being limited to the grounds relied upon by the applicant in the notice of review, promptly submit a new draft decision to the Governing Council. This new decision either abrogates the initial decision, replaces it with a decision of identical content, or replaces it with an amended decision. It shall be deemed adopted unless the Governing Council objects to it within a maximum period of ten working days. Crucially, a review of this new decision of the Governing Council cannot be requested before the ABR. In this case, if the applicant wants to appeal the new decision, the only available avenue is applying for judicial review with the CJEU under Art 263 TFEU.

\subsection{Appeal Panel of the SRM}

The SRM Regulation ${ }^{45}$, Art 85, provides for the establishment of an Appeal Panel (AP) to hear claims concerning the decisions of the Single Resolution Board. The Single Resolution Board (SRB), which was established on 1 January 2015 and is operative since $1^{\text {st }}$ January 2016, is a Brussels based agency with legal personality and independent finances. In its plenary session, the SRB comprises its chair, the vice-chair, four permanent members and representatives of the national resolution authorities of all participating Member States. The ECB and the European Commission have observer status in the SRB. The SRB is the resolution authority of the Banking Union, and it was set up in order to ensure an orderly resolution of failing banks in participating Member States, with minimum impact on public finances and taxpayers.

-What can be challenged?

\footnotetext{
${ }^{45}$ For an overview: Christos Gortsos, The Single Resolution Mechanism (SRM) and the Single Resolution Fund (SRF). A comprehensive review of the second main pillar of the European Banking Union (ECEFIL, $2^{\text {nd }}$ ed, 2016) 67.
} 
The AP can hear appeals lodged against a decision of the Board referred to in Article 10(10) on the assessment of resolvability, Article 11 on the application of simplified obligations or the waiver of the obligation to draft resolution plans, Article 12(1) on the minimum requirements for own funds and eligible liabilities, Articles 38 to 41 on the imposition of fines and periodic penalty payments, Article 65(3) on the contribution to the board's administrative expenditures, Article 71 on the raising of extraordinary ex-post contribution and Article 90(3) on access to documents ${ }^{46}$. Finally, it is worth noting that there is no possibility to appeal the decisions regarding actual bank resolution under Art. 18 of the Regulation.

-By whom?

As far as the rules on standing are concerned, Art 85(3) SRM Regulation uses the usual formulation, that the decision has to be addressed to the natural or legal person challenging it, or has to be of "direct and individual concern". The applicant has six weeks to appeal.

-On what grounds?

The legislation does not mention on what grounds can the AP review the decisions. It is therefore debatable whether the applicant can question only the legality of the challenged measure or also extend the claim to the substantial correctness of the relative technical evaluations. Chirulli and De Lucia hold the opinion that, given the open wording of the specific norm, which refer only to "the complaint of the interested party", the applicant is not barred to challenge the decision even on substantive grounds. This means that AP would be able to review procedural and technical aspects as well as the merits of the contested decision ${ }^{47}$.

- What are the Effects?

An appeal lodged pursuant to paragraph 3 shall not have suspensive effect.

However, the Appeal Panel may, if it considers that circumstances so require, suspend the application of the contested decision ${ }^{48}$. The Appeal Panel may only either confirm the decision taken by the Board, or remit the case to the latter. The Board shall be bound by the decision of Appeal Panel and it shall adopt an amended decision regarding the case concerned ${ }^{49}$

The decision of the Board of Appeal is binding, and, under Art 86(1), it can be challenged before the CJEU: in accordance with art 263 TFEU contesting a decision taken by the Appeal Panel or, where there is no right of appeal to the Appeal Panel, by the Board. Or under 265 for failure to act of the board.

\subsection{Areas of tension}

\footnotetext{
${ }^{46}$ Art 85(3) SRM Regulation.

${ }^{47}$ Paola Chirulli and Luca De Lucia, "Specialised Adjudication in EU Administrative Law: the Boards of Appeal of EU agencies" (2015) European Law Review 832, 846.

${ }^{48}$ 85(6) SRM Regulation.

${ }^{49}$ 85(8) SRM Regulation.
} 
Neither the Administrative Board of review nor the Appeal Panel have yet handled a single case. Therefore, at this stage, only a description of the potential legal issues is possible. It is however already apparent that the law which set up these bodies give rise to some tensions: there are issues, faced by the natural or legal person who lodges the appeal (the applicant) of transparency, of cost, and of procedural safeguards.

To begin with, the ABR does not have binding powers. It means that it is always the Supervisory Board who has the ultimate saying on the matter, since it can disregard the opinion of the ABR and re-adopt a decision of identical content (subject to the Governing Council not objecting within ten days $)^{50}$. The independent body, therefore, does not really act as a judicial organ and its powers are very limited. The SSM Regulation at Art 24(11) states that the setting up and functioning of the ABR is without prejudice to the right to bring proceedings before the CJEU in accordance with the Treaties.

However, starting proceeding before the CJEU, which is possible both under Art 24(11) SSM Regulation and under Art 86(1) SRM Regulation, is costly and time consuming (procedural economy was indeed one of the reasons for the creation of the ABR). In particular, as far the $\mathrm{SRM}$ is concerned, it is possible to appeal decisions of the BoA to the CJEU, or those decisions of the SRB where there is no appeal possibility to the Panel. Such actions to the CJEU must be brought in accordance with Art. 263 TFEU. If the action is well founded, the CJEU is to declare the act concerned to be void (Art. 264 TFEU). Proceedings before the CJEU are not only burdensome in terms of money ${ }^{51}$, but also in terms of time ${ }^{52}$. The time element is particularly striking if compared The particular nature of the decisions taken especially by the SRB makes it so that having to wait, in average, more than one year before the CJEU issues a ruling ${ }^{53}$, frustrates the purpose of the decision and of the review.

Another fundamental problem is that it may be difficult if not impossible for applicants to comply with the time limitation of Art 263(6) TFEU (within two months of the publication of the measure, or of its notification to the plaintiff, or, in the absence thereof, of the day on which it came to the knowledge of the latter, as the case may be), if they have to pass through the AP or the ABR before. This problem is avoided only if the applicants can challenge the new decision (that substitutes the previous one, even if identical) within those time limits.

The proceedings before the ABR and the AP also presents difficulties in access to documents. The two panels cannot undertake any further investigation or collect fresh evidence on their own

\footnotetext{
${ }^{50}$ Art 24(7) SSM Regulation.

${ }^{51}$ Even though proceedings before the CJEU are not necessarily more costly than those before the appeal panels. The other Appeal Panels of EU agencies foresee an application costs, the CJEU does not. The AP of the SRM and the ABR have not yet established an application cost to begin proceedings before them.

${ }^{52}$ See the Court's case law on lengthy proceedings C ase C 50/12 P, Kendrion v Commission [2013] ECR- 771, Case C 58/12 P, Groupe Gascogne [2013] ECR 770, Case C 40/12 P, Gascogne [2013] 768. Proceedings of reasonable duration are a right under Article 47 of the Charter (which provides that "everyone is entitled to a fair and public hearing within a reasonable time by an independent and impartial tribunal established by law") and are related to the principle of effective judicial protection.

53 "In the case of direct actions, the average time in 2015 was 17.6 months, which amounts to a significant reduction compared with the preceding years (between 19.7 months and 24.3 months in the period from 2011 to 2014 )" http://curia.europa.eu/jcms/upload/docs/application/pdf/2016-03/cp160034en.pdf .
} 
initiative ${ }^{54}$.

Moreover, as Chirulli and De Lucia noted ${ }^{55}$, even though the European Courts define them as "quasi-jurisdictional bodies" ${ }^{56}$, the board of appeals of EU agencies in general (and thus certainly the SRM AP) do not have formal judicial powers and cannot be considered courts. This means that the applicant cannot properly rely on a right to a "fair hearing" 57 .

Finally, it could be argued ${ }^{58}$ that the lack of a possibility to appeal the decisions on resolution is an infringement of the right to property enshrined in the Unions Charter of Fundamental Rights (Art. 17(1)), and the CJEU has also recognised this for the first time in Case 44/79 Hauer. ${ }^{59}$

\section{The lesson from APD}

The study of American political development-APD - emerged in the early 1980s as subfield of the study of American Politics. It seeks to analyse political contemporary phenomena through a diachronic lens ${ }^{60}$. APD as a field of study is shaped by historians, economists, lawyers and political scientists alike. The field has been described as "insurgent" because it "brings the idea that "history matters" into the center of political analysis and prizes fresh answers to questions that are never taken for granted within APD",61

APD has studied the simultaneous transformation of institutions and polity, and how these generated substantial protest about prevailing economic and democratic conditions. The dynamics that were encountered by the US (expanding market, expanded administrative capacity, trade-off between democratic legitimacy and economic efficiency, market activities, and corresponding industrial developments, and durable inequalities) are relevant for the current debates in Europe. It is so because the EU can draw lessons from the regulatory and administrative mechanisms which, in $19^{\text {th }}$ century America, fostered market consolidation. ${ }^{62}$

Scholars of the EU have had recourse to APD both to explain other EU policy-making areas ${ }^{63}$ as they have in order to deal with economic governance ${ }^{64}$ or fundamental rights ${ }^{65}$ by comparing the

\footnotetext{
${ }^{54}$ Art 15 ABR Decision

${ }^{55}$ Chirulli and De Lucia (n 47)

${ }^{56}$ Case T-133/08, Schräder v CPVO - Hansson [2010] ECR 430, par 137 and 190.

${ }^{57}$ Case T-63/01, Procter \& Gamble v OHIM [2002] ECR II-5255.

${ }^{58}$ See eg the Finnish report, FIDE XXVII Cogress (Vol 1, Wolters Kluwer 2016) 21.

${ }^{59}$ Case 44/79 Liselotte Hauer v Land Rheinland-Pfalz [1979] ECR I-3727.

${ }^{60}$ The fundamental work by Paul Pierson, "Politics in Time" for example, has a threefold purpose: to advocate that political scientists situate arguments in temporal perspective, to illustrate a number of ways in which they might do so, and to argue that much of the discipline does not presently take time seriously enough. Paul Pierson. Politics in Time: History, Institutions, and Social Analysis. (Princeton University Press 2004).

${ }^{61}$ Suzanne Mettler and Richard Valelly, "The Distinctiveness and Necessity of American Political Development" in Richard Valelly, Suzanne Mettler, and Robert Lieberman (eds), The Oxford Handbook of American Political Development (OUP 2016).

${ }^{62}$ Egan, Single Markets: Economic Integration in Europe and the United States (OUP 2015).

${ }^{63}$ Anand Menon, "Defence Policy and the European State: Insights from American Experience" in D King and P Le Gales (eds), The Reconfiguration of the State in Europe (OUP 2015). Robert Schütze, From Dual to Cooperative Federalism. The Changing Structure of European Law (OUP 2009) 59.

${ }^{64}$ Federico Fabbrini, Economic Governance in Europe: Comparative Paradoxes and Constitutional Challenges
} 
EU's experience to an external benchmark (the US). When it comes to economic governance, literature on both sides of the Atlantic has focused on the path that, through market relations ${ }^{66}$, have accompanied the move from singular states to unions ${ }^{67}$.

These studies have considered factors - from corporate governance structures to issues of state sovereignty - which had an impact on administration and regulation. Crucially, the key finding for EU lawyers is that the development of the US in the $19^{\text {th }}$ century has resulted in a significant expansion of the institutional capacity of the American state over two centuries with a similar discernible pattern of institutional development in Europe ${ }^{68}$.

In terms of administrative capacities, the standard narrative is that before the Civil War the US was a relatively weak state ${ }^{69}$. This was also true with regard to military capacity. ${ }^{70}$ However, authors such Mashaw and Perry have pointed out that the State weakness, if it existed, had no influence on the development of administrative capacity ${ }^{71}$. The account of the surge of the American State considers that it was vastly strengthened after the Civil War, for it had to respond to pressures to increase its security requirements. This critic period has been a major turning point in US administrative law. Thus, military capacity as an essential element of state-building was a catalyst of American development ${ }^{72}$.

\section{Independent agencies in American development}

The end of the Civil War also witnessed the birth of the modern independent regulatory agency, which emerged at the federal level began in the late nineteenth century. The first was the Interstate Commerce Commission, instituted in 1887 by the Congress. The ICC was the first

\footnotetext{
(OUP 2016).

${ }^{65}$ Federico Fabbrini, Fundamental Rights in Europe: Challenges and Transformations in Comparative Perspective (OUP 2014)

${ }^{66}$ Michelle Egan (n 62); M Egan "Toward a New History in European Law: New Wine in Old Bottles" (2013) 28 (5) American University International Law Review 1223; M Egan, "Single Market" in E Jones, A Menon and S Weatherill, The Oxford Handbook of the European Union (OUP 2012); Michelle Egan, "The Emergence of the US Internal Market", in J. Pelkmans, D. Hanf, and M.Chang (eds), The EU Internal Market in Comparative Perspective: Economic, Political, and Legal Perspectives (Peter Lang Publishers 2008).

${ }^{67}$ A Glencross, What Makes the EU Viable? European Integration in the Light of the Antebellum US Experience (Palgrave Macmillan 2007); A Moravcsik, "In Defence of the 'Democratic Deficit': Reassessing Legitimacy in the European Union." (2002) 40 (4) JCMS: Journal of Common Market Studies 603; A Menon, and M. A. Schain (eds), Comparative Federalism: The European Union and the United States in Comparative Perspective (OUP 2006); JD Donahue and M. A. Pollack, "Centralization and its Discontents: The Rhythms of Federalism in the United States and the European Union" in K. Nicolaïdis and R. Howse (eds), The Federal Vision: Legitimacy and Levels of Governance in the United States and the European Union (OUP 2001)

${ }^{68}$ Egan (n 62); Pollack, S. 2009. War, Revenue, and State Building: Financing the Development of the American State. Ithaca, NY; Cornell University Press.

${ }^{69}$ Keohane, R. O. 2002. "International Commitments and American Political Institutions in the Nineteenth Century." In Shaped by War and Trade: International Influences on American Political Development, ed. I. Katznelson and M. Shefter. Princeton, NJ: Princeton University Press.

${ }^{70}$ Anand Menon, "Defence Policy and the European State: Insights from American Experience" in D King and P Le Gales (eds), The Reconfiguration of the State in Europe (OUP 2015).

${ }^{71}$ Mashaw and Perry (n 18)

${ }^{72}$ Shaped by War and Trade: International Influences on American Political Development, ed. I. Katznelson and M. Shefter. Princeton, NJ: Princeton University Press. 83
} 
federal agency, but even before its establishment several states utilized the regulatory commission structure in their attempts to regulate the railroad industry. ${ }^{73}$

After the ICC was set up, the US saw, together with the centralisation of power ${ }^{74}$ and the rebuilding of the nation state ${ }^{75}$ an increase in its administrative capacities to regulate phenomena of federal interest. An aspect of this renewal of Washington's power was an outgrowth of federal agencies (which in turn derived from the state commission movement which dated back to the early Nineteenth century ${ }^{76}$ ). The work of Mashaw as well links the centralisation of national administrative law with the growth and development of national administrative statutory law in three phases ${ }^{77}$. As Egan sums up, "[t] he expansive role for administrative discretion emerged under broad delegations of Congressional authority that generated substantial regulatory activity on the part of administrative agencies, contributing towards the consolidation and growth of state power, through permissive acceptance of administrative adjudicatory and enforcement authority" 78 .

However, much as for the Banking Union agencies considered earlier in this paper, a remarkable feature of the agencies established at the federal level in the Nineteenth century was the scant need felt for executive direction and control, including, crucially, little judicial review of administrative action. ${ }^{79}$ More generally, a recent commentator of US administrative law has considered that "The administrative state seems to have a democracy problem" and that "concern over the democratic legitimacy of administrative power, together with related concerns over its constitutionality, have been abiding preoccupations for scholars, officials, and reformers" ${ }^{\prime 80}$. The state of the play on judicial review of executive acts was expressed in a punchy sentence by one the authorities of US administrative law, Kenneth Culp Davis: "The presumption was one of unreviewability throughout the 19th century.",

This attitude of several actors involved is derived not only from the ruling of Courts, but also from the behaviour of states attorneys. As far as the Supreme Court is concerned, Breger and Edles state that "over the course of the nineteenth century, the Court was extremely reluctant to

\footnotetext{
${ }^{73}$ Breger Edles (n 21) 20

${ }^{74}$ Donahue and M. A. Pollack (n 67) 85

${ }^{75}$ Skowroneck (n 17)

${ }^{76}$ Robert Cushman, The Independent Regulatory Commissions 26 (1972) (“[I]n 1887, ten states had set up 'strong' commissions... possessing actual rate-making powers.").

${ }^{77}$ J. L. Mashaw, 2006. "Recovering American Administrative Law: Federalist Foundations, 1787-1801." Yale Law Journal 115 (6): 1256-344; Mashaw, J. L. 2007. "Reluctant Nationalists: Federal Administration and Administration Law in the Republican Era, 1801-1829." Yale Law Journal, 116 (8): 1636-740 ; Mashaw, J. L., and A. Perry (n 18).

${ }^{78}$ Egan (n 62).

${ }^{79}$ Frederic P. Lee, The Origins of Judicial Control of Federal Executive Action, 36 Geo. L.J. 287, $292-93$ (1948); Ann Woolhandler, Judicial Deference to Administrative Action-A Revisionist History, 43 Admin. L. Rev. 197,221 (1991).

${ }^{80}$ Jud Mathews, "Minimally Democratic Administrative Law" Administrative Law Review, Forthcoming Penn State Law Research Paper No. 8-2016, 2.

815 kenneth culp davis, administrative law treatise $\S 28: 1$, at 254 (2d ed. 1984). In Decatur v. Paulding, the Supreme Court observed that " $\mathrm{t}]$ he interference of the Courts with the performance of the ordinary duties of the executive departments of the government, would be productive of nothing but mischief; and we are quite satisfied that such a power was never intended to be given to them."
} 
review executive decisions. As an example - albeit extreme from a modern perspective - the Court refused to compel the secretary of the navy to pay Stephen Decatur's widow her pension, as required by a private act of Congress. Decatur v. Paulding ${ }^{82}$. Rather than ruling on the merits, the Court held that it lacked jurisdiction because the action fell within the secretary's discretionary power" ${ }^{\prime 3}$. Equally, state attorneys (then called district attorneys) enjoyed considerable independence from the executive branch. ${ }^{84}$ This is because early attorneys general understood the opinions clause of the Judiciary Act of $1789,{ }^{85}$ to be a limitation on their authority, rather than the basis to control legal opinions throughout the executive branch. ${ }^{86}$ The state attorneys' interpretation allowed district attorney to conduct federal prosecution free from the control and jurisdiction of the attorney general ${ }^{87}$.

Even though this "minimalist" 88 approach to judicial review of executive power was reconsidered following the Civil War, it was only in 1897, that the Supreme Court reviewed an ICC act ${ }^{89}$. And the presumption of unreviewability, however, was not reversed until the Court's 1902 decision in American School of Magnetic Healing v. McAnnulty. ${ }^{90}$ Judicial reviewability of agency action in the post-Administrative Procedure Act (APA) era was later expressly established in Abbott Laboratories v. Gardner ${ }^{91}$.

Notwithstanding this "democratic deficit" and the problems of legal accountability of the $19^{\text {th }}$ century agencies, several studies suggest that it was precisely the expansion of administrative law and steady growth of regulation to achieve market consolidation that strengthened the role of the state and underpinned American political-economic development ${ }^{92}$.

It is worth mentioning that today, judicial review of agency action is thought as beneficial also because of "information forcing", in the sense that it helps other branches of State to acquire

\footnotetext{
8239 U.S. 497, 513-14 (1840).

${ }^{83}$ Breger and Edles (n 21) 22 n 19.

${ }^{84}$ See Albert Langeluttig, The Department Of Justice Of The United States 2 (1927) (providing a historical account of the Department of Justice and noting that "[t]he Attorney General was given no supervision or control over the district attorneys"); Charles Tiefer, The Constitutionality of Independent Officers as Checks on Abuses of Executive Power, 63 B.U. L. REV. 59, 74-75 (1983)

${ }^{85}$ See Judiciary Act of 1789 , ch. $20, \S 35,1$ Stat. 73, 93 (authorizing the attorney general to provide legal opinions and advice to the president and department heads).

${ }^{86}$ See Lawrence Lessig, Readings by Our Unitary Executive, 15 Cardozo 1. rev. 175, 183-85 (1993); see also Keith S. Brown \& Adam Candeub, independent agencies and the unitary executive debate: an empirical critique 10 (Mich. State Univ. College of Law, Legal Studies Research Paper Series, Research Paper No. 06-04), available at http://papers.ssrn.com/sol3/papers.cfm?abstract_id=1100125\#\# ("While the Judiciary Act of 1789 did create the office of Attorney General, it did not create a 'department' under him.").

${ }^{87}$ For a full account, Breger and Edles (n 21) 20-22.

${ }^{88}$ I borrow this expression from Jud Mathews (n 80).

${ }^{89}$ The SC rejected the ICC's conclusion that its statutory power to determine the reasonableness of rates included the power to prescribe rates. Interstate Commerce Comm'n v. Cincinnati, New Orleans \& Tex. Pac. Ry. Co., 167 U.S. 479, 500 (1897).

90187 U.S. 94 (1902).

${ }^{91}$ Abbott Labs. v. Gardner, 387 U.S. 136, 140 (1967).

${ }^{92}$ Novak, W. J. 1994. "Common Regulation: Legal Origins of State Power in America." Hastings Law Journal 45 (4): 1061-97; Keller, M. 1977. Affairs of State: Public Life in Late Nineteenth Century America. Cambridge, MA: The Belknap Press of Harvard University Press; Horwitz, M. J. 1977. The Transformation of American Law, 17801860. Cambridge, MA: Harvard University Press.
} 
useful information from the agency ${ }^{93}$. Moreover, judicial review ensures that the agency bases its decision on a reasoned analysis of relevant information": "Fully aware of the consequences of a judicial remand, the agencies are constantly 'looking over their shoulders' at the reviewing courts in preparing supporting documents, in writing preambles, in responding to public comments, and in assembling the rulemaking 'record."' 95. An aspect of Judicial Review of independent agencies action is the so called Chevron deference, which consists of a two-steps enquiry: two-step inquiry -whether Congress has left a statutory ambiguity and if the agency's interpretation in resolving this ambiguity is reasonable. If the test is met, then the Court cannot review the statutory interpretation made by the agency. However, some authors have argued against applying Chevron deference to independent agencies. In particular, Randolph May is championing the cause of jurisprudential change in this area. ${ }^{96} \mathrm{He}$ argues on the grounds of accountability, separation of powers and democratic concerns that judicial review should be more intense in the case of independent agencies because their characteristics diminish their democratic pedigree.

\section{Conclusion}

What is the Banking Union and what may be its developments? This paper has argued that the APD offers a conceptual framework to theorise the role of independent agencies and their internal mechanisms of review. Further research may expand the analysis to the whole Banking Union system and offer a theoretical framework for understanding its standing under administrative law.

European lawyers can learn a great deal from the US political development, as the abundant literature on the comparison between the two entities witnesses. This paper has concentrated on the newest developments of the Banking Union, and has found that the lesson from the US can be of tolerating the constant tension between independent, unelected agencies and the commitment of being governed by the people.

In order to tackle the Eurozone sovereign crisis, the EU has adopted a new legal structure, the Banking Union, for the supervision and resolution of participating MSs credit institutions. As part of the SSM and of the SRM, a de facto agency (the Supervisory Board in the ECB) and an

\footnotetext{
${ }^{93}$ Matthew C. Stephenson, A Costly Signaling Theory of “Hard Look” Judicial Review, 58 ADMIN. L. REV. 753, 755-56 (2006) (arguing that both the executive and judiciary overcome their informational disadvantage by forcing information out of the agencies in the form of detail, polish, and thoroughness of their explanations); Emerson H. Tiller, Resource-Based Strategies in Law and Positive Political Theory: Cost-Benefit Analysis and the Like, 150 U. PA. L. REV. 1453, 1459 (2002) (arguing that the essence of hard-look review is to attack the reasoning processes of the regulator and force it to spend more of its resources on producing information).

${ }^{94}$ Sharkey, Catherine M., "State Farm 'with Teeth': Heightened Judicial Review in the Absence of Executive Oversight" (2014). New York University Public Law and Legal eory Working Papers. Paper 463, 117

95 Thomas O. McGarity, Some Thoughts on "Deossifying” the Rulemaking Process, 41 DUKE L.J. 1385,1412 (1992).

${ }^{96}$ Randolph J. May, Defining Deference Down: Independent Agencies and Chevron Deference, 58 ADMIN. L. REV. 453 (2006).
} 
agency (the SRB) have been instituted. The article has considered the legal issues arising from the possible judicial review of these agencies' acts, and has highlighted the main concern on the legal accountability of these bodies, and on the effective judicial protection of applicants who wish to challenge the agencies' decisions.

The decision to delegate power to agencies has major repercussion on the fundamental political organisation of the polity ${ }^{97}$, in the EU much as it had in the US.

Worryingly low standards of judicial review have been studied in the American experience of political and administrative development in the second half of the $19^{\text {th }}$ century. To control critical areas of the common market - namely those which may have been subject to monopolies, such as roads and railways - the federal state developed also through an outgrowth of independent agencies, which, at least initially, enjoyed large discretion and were not subject to judicial review.

Notwithstanding this "democratic deficit" and the problems of legal accountability of the $19^{\text {th }}$ century agencies, it was precisely the expansion of administrative law and steady growth of regulation to achieve market consolidation that strengthened the role of the state and underpinned American political-economic development.

Integration of complex polities such as that of the US as it emerged from the Civil War, and of the EU as it is now, passes through phases of market building in which it may be necessary, for the expansion and strengthening of the State's administrative capacity, to overlook concerns of judicial protection. The delegation of highly discretionary power may be a necessitated step.

\section{Bibliography}

Breger MJ and Edles GJ, Independent Agencies in the United States: Law, Structure, and Politics (OUP 2015)

Brown KS and Candeub A, "Independent Agencies and the Unitary Executive Debate: an Empirical Critique Mich. State Univ. College of Law, Legal Studies Research Paper Series, Research Paper No. 06-04), available at http://papers.ssrn.com/sol3/papers.cfm?abstract_id=1100125\#\#

Chirulli P and De Lucia L, "Specialised adjudication in EU administrative law: the Boards of Appeal of EU agencies" (2015) European Law Review 832

Craig P, EU Administrative Law (OUP 2012) 144-146

Culp Davis K, Administrative Law Treatise (2d ed. 1984)

Directorate General for internal policies, "The General Principles of EU Administrative Procedural Law"2015

\footnotetext{
${ }^{97}$ G Majone, "Delegation of Regulatory Powers in a Mixed Polity" (2002) 8 ELJ 319, 322
} 
Cushman R, The Independent Regulatory Commissions (1972)

Donahue JD and Pollack MA, "Centralization and its Discontents: The Rhythms of Federalism in the United States and the European Union" in K. Nicolaïdis and R. Howse (eds), The Federal Vision: Legitimacy and Levels of Governance in the United States and the European Union (OUP 2001)

Egan M, Single Markets: Economic Integration in Europe and the United States (OUP 2015)

-- --, "Toward a New History in European Law: New Wine in Old Bottles" (2013) 28 (5) American University International Law Review 1223

-- --, "Single Market" in E Jones, A Menon and S Weatherill, The Oxford Handbook of the European Union (OUP 2012)

-- --, "The Emergence of the US Internal Market", in J. Pelkmans, D. Hanf, and M.Chang (eds), The EU Internal Market in Comparative Perspective: Economic, Political, and Legal Perspectives (Peter Lang Publishers 2008)

Fabbrini F, Economic Governance in Europe: Comparative Paradoxes and Constitutional Challenges (OUP 2016)

-- --, Fundamental Rights in Europe: Challenges and Transformations in Comparative Perspective (OUP 2014)

Ferran E, Moloney N, Payne J (eds), The Oxford Handbook of Financial Regulation (OUP 2015)

Glencross A, What Makes the EU Viable? European Integration in the Light of the Antebellum US Experience (Palgrave Macmillan 2007)

Gortsos C, The Single Resolution Mechanism (SRM) and the Single Resolution Fund (SRF). A comprehensive review of the second main pillar of the European Banking Union (ECEFIL, $2^{\text {nd }}$ ed, 2016)

Hadjiemmanuil C, "Bank Resolution Financing in the Banking Union" LSE Law, Society and Economy Working Papers 6/2015

Harlow C and Rawlings R, "Process and Procedure in EU Administration (Hart Publishing 2014) 294

Horwitz MJ, The Transformation of American Law, 1780-1860 (Harvard University Press 1977)

Keller M, Affairs of State: Public Life in Late Nineteenth Century America (The Belknap Press of Harvard University Press 1977)

Keohane R, "International Commitments and American Political Institutions in the Nineteenth Century" in I. Katznelson and M. Shefter (eds), Shaped by War and Trade: International Influences on American Political Development, (Princeton University Press 2002)

Langeluttig A, The Department Of Justice Of The United States 2 (1927) 
Lee F, The Origins of Judicial Control of Federal Executive Action (1948) 36 Geo. L.J. 287

Lessig L, Readings by Our Unitary Executive (1993) 15 Cardozo 1. rev. 175

Majone G, "Delegation of Regulatory Powers in a Mixed Polity" (2002) 8 ELJ 319, 322

Mashaw JL, "Recovering American Administrative Law: Federalist Foundations, 1787-1801" (2006) Yale Law Journal 115 (6): 1256-344

-- --, "Reluctant Nationalists: Federal Administration and Administration Law in the Republican Era, 1801-1829” (2007) Yale Law Journal, 116 (8): 1636-740

-- -- and Perry A, "Administrative Statutory Interpretation in the Antebellum Republic." (2009)

7 Michigan State Law Review 7-49

Mathews J, "Minimally Democratic Administrative Law" Administrative Law Review, (Forthcoming); Penn State Law Research Paper No. 8-2016

May RJ, Defining Deference Down: Independent Agencies and Chevron Deference (2006) 58 ADMIN. L. REV. 453

McGarity T, Some Thoughts on "Deossifying” the Rulemaking Process (1992) 41 DUKE L.J. 1385,1412

Menon A, "Defence Policy and the European State: Insights from American Experience" in D King and P Le Gales (eds), The Reconfiguration of the State in Europe (OUP 2015)

-- -- and Schain MA (eds), Comparative Federalism: The European Union and the United States in Comparative Perspective (OUP 2006)

Mettler S and Valelly R, "The Distinctiveness and Necessity of American Political Development" in Richard Valelly, Suzanne Mettler, and Robert Lieberman (eds), The Oxford Handbook of American Political Development (OUP 2016)

Moloney N, European Banking Union: Assessing its Risks and Resilience.

Moravcsik A, "In Defence of the 'Democratic Deficit': Reassessing Legitimacy in the European Union" (2002) 40 (4) Journal of Common Market Studies 603

Novak WJ, "Common Regulation: Legal Origins of State Power in America" (1994) 45 (4) Hastings Law Journal 1061

Pierson P, Politics in Time: History, Institutions, and Social Analysis (Princeton University Press 2004)

Pollack S, War, Revenue, and State Building: Financing the Development of the American State. (Cornell University Press 2009) 
Salminen J and Tuominen T, Finnish report, FIDE XXVII Cogress (Vol 1, Wolters Kluwer 2016)

Schuster G et als, The SSM Framework Regulation. Part 2: Administrative procedure, legal remedies and transitional provisions, June 2014

Schütze R, From Dual to Cooperative Federalism. The Changing Structure of European Law (OUP 2009)

Shapiro M, The Problem of Independent Agencies in the United States and the European Union (1997) 4 Journal of European Public Policy 276.

Sharkey CM, "State Farm 'with Teeth': Heightened Judicial Review in the Absence of Executive Oversight" New York University Public Law and Legal theory Working Papers. Paper 463/2014

Skowroneck S, Building a New American State. The Expansion of National Administrative Capacities, 1877-1920 (CUP 1982).

Stephenson M, "A Costly Signaling Theory of "Hard Look" Judicial Review" (2006) 58 ADMIN. L. REV. 753

Tiefer C, The Constitutionality of Independent Officers as Checks on Abuses of Executive Power (1983) 63 B.U. L. REV. 59

Tiller EH, Resource-Based Strategies in Law and Positive Political Theory: Cost-Benefit Analysis and the Like (2002) 150 U. PA. L. REV. 1453

Verkuil P, The Purposes and Limits of Independent Agencies (1988) 37 Duke Law Journal 257

Woolhandler A, Judicial Deference to Administrative Action-A Revisionist History (1991) 43 Admin. L. Rev. 197 